\title{
Science/Education Portraits VII: Statistical Methods Used in 1081 Papers Published in Year 2020 Across 12 Life Science Journals Under BioMed Central
}

\author{
Kyle D Kim ${ }^{1,2}$, Shaun CH Chua ${ }^{3}$ and Maurice HT Ling ${ }^{1-4 *}$ \\ ${ }^{1}$ Department of Applied Sciences, Northumbria University, United Kingdom \\ ${ }^{2}$ School of Life Sciences, Management Development Institute of Singapore, \\ Singapore \\ ${ }^{3}$ School of Applied Sciences, Temasek Polytechnic, Singapore \\ ${ }^{4}$ HOHY PTE LTD, Singapore \\ *Corresponding Author: Maurice HT Ling, Department of Applied Sciences, \\ Northumbria University, United Kingdom.
}

Received: January 22, 2021

Published: February 12, 2021

(C) All rights are reserved by Maurice HT

Ling., et al.

\begin{abstract}
Statistics is an integral part of biology and is required for all undergraduate life science curriculum. However, are biology students trained in statistical skills required in the field? Despite studies listing various commonly statistical methods used in specialised branches of life sciences; such as, immunology and tropical biology; there is a lack of study on the common statistical methods used in life science in general. Here, we examine 1081 articles across 12 life sciences journals under BioMed Central, published in 2020, to elucidate the common statistical methods used in current life science research, as a basis to recommend an updated syllabus to all institutions that educate biologists. $72.7 \%$ of the examined articles contains identifiable statistical methods and a total of 2431 instances were identified. Our findings show that the first 3 out of 15 categories of methods; parametric comparison of means (25.38\% of instances), correlation/regression (18.88\%), and post-hoc test (10.32\%); accounts for 54.59\% of the instances. In terms of individual methods, the top 8 methods account for $52.04 \%$ of the instances - (a) t-test (13.00\%), (b) ANOVA (12.26\%), (c) unspecified (likely to be Pearson's correlation) and Pearson's correlation (9.79\%), (d) Benjamini and Hochberg's False Discovery Rate (FDR) (4.77\%), (e) Tukey's HSD (4.36\%), (f) Kruskal-Wallis Test (2.96\%), (g) Mann-Whitney U Test (2.80\%), and (h) Chi Square Test (2.10\%). These findings may have an impact on future curriculum design.
\end{abstract}

Keywords: Statistical Methods; Life Science; Research; Education

\section{Introduction}

The importance of statistics in biology has been recognized more than a century ago [1]. With increasing number of statistical methods, there is a concern regarding core statistical fundamentals required in a biologist's education [2-6]. Lee., et al. [5] review articles in six pharmacy journals and found (a) ANOVA, (b) ChiSquare Test, (c) Student's t-Test, (d) Pearson's Correlation Coeffi- cient, and (e) Logistic Regression; as the five most commonly used inferential statistical methods. Loaiza Velásquez., et al. [2] review the statistical methods used in two tropical journals during a year and identified twelve most frequently used methods as (a) ANOVA, (b) Chi-Square Test, (c) Student's t-Test, (d) Linear Regression, (e) Pearson's Correlation Coefficient, (f) Mann-Whitney U Test, (g) Kruskal-Wallis Test, (h) Shannon's Diversity Index, (i) Tukey's Test, 
(j) Cluster Analysis, (k) Spearman's Rank Correlation Test, and (l) Principal Component Analysis. It is crucial that biology students are trained in required statistical skills [2].

However, Lee., et al. [5] focus on pharmacy while Loaiza Velásquez., et al. [2] focus on tropical biology. Similar work by Skinner [6], Meyr [7], Al-Benna., et al. [8], and Hammer and Buffington [9] focus on immunology, surgery, burns research, and veterinary medicine respectively. Hence, the statistical methods used in the common denominator, life science in general, can only be inferred. Here, we identify the statistical methods used in 1081 articles across 12 life sciences journals under BioMed Central published in 2020 as a basis to recommend an updated syllabus to all institutions that educate biologists.

\section{Methods}

Using similar methods in previous studies $[2,5,7,8]$, twelve open access journals from BioMed Central that are indexed in PubMed [(a) Biological Research, (b) BMC Bioinformatics, (c) BMC Biology, (d) BMC Ecology, (e) BMC Evolutionary Biology, (f) BMC Genomics, (g) BMC Microbiology, (h) BMC Molecular and Cell Biology, (i) Cell and Bioscience, (j) Genome Biology, (k) Journal of Animal Science and Biotechnology, and (l) Stem Cell Research and Therapy] were selected for survey. For each of the twelve journals, all articles published from January 01, 2020; to the end of the month where the number of articles exceed 100 were chosen, or to the end of October 2020. This is to prevent an over-representation of a specific journal in the survey. For each published article, identifiable statistical method(s) used were collated and each method was recorded only once per article [5] with no judgement made on the suitability of the methods [7].

\section{Results and Discussion}

In this study, we examined 1081 peer-reviewed articles published across 12 open access journals from BioMed Central to collate the statistical methods used. The minimum 2-year and 5-year impact factors (as of October 2020) are 2.381 and 2.922 respectively (Table 1), with the highest 2-year impact factor at 10.806; suggesting that the 12 open access journals are highly reputable. Hence, the statistical methods used is likely to be reflective of the needs of the field and important support for curriculum development [2].

\begin{tabular}{|l|c|c|c|c|}
\hline Journal Name & $\begin{array}{c}\text { 2-year } \\
\text { Impact } \\
\text { Factor }\end{array}$ & $\begin{array}{c}\text { 5-year } \\
\text { Impact } \\
\text { Factor }\end{array}$ & $\begin{array}{c}\text { Source } \\
\text { Normalized } \\
\text { Impact per } \\
\text { Paper (SNIP) }\end{array}$ & $\begin{array}{c}\text { SCImago } \\
\text { Journal } \\
\text { Rank } \\
\text { (SJR) }\end{array}$ \\
\hline $\begin{array}{l}\text { Biological } \\
\text { Research }\end{array}$ & 3.092 & 2.968 & 0.939 & 0.841 \\
\hline $\begin{array}{l}\text { BMC } \\
\text { Bioinformatics }\end{array}$ & 3.242 & 3.213 & 1.156 & 1.626 \\
\hline BMC Biology & 6.765 & 7.296 & 1.604 & 3.698 \\
\hline BMC Ecology & 2.381 & 2.922 & 0.913 & 1.030 \\
\hline $\begin{array}{l}\text { BMC } \\
\text { Evolutionary } \\
\text { Biology }\end{array}$ & 3.058 & 3.252 & 1.198 & 1.531 \\
\hline BMC Genomics & 3.594 & 4.093 & 1.140 & 1.629 \\
\hline $\begin{array}{l}\text { BMC } \\
\text { Microbiology }\end{array}$ & 2.989 & 3.381 & 1.049 & 1.154 \\
\hline $\begin{array}{l}\text { BMC } \\
\text { Molecular and } \\
\text { Cell Biology }\end{array}$ & 3.066 & 2.684 & 1.023 & 1.070 \\
\hline $\begin{array}{l}\text { Cell and } \\
\text { Bioscience }\end{array}$ & 5.026 & 4.443 & 0.985 & 1.410 \\
\hline $\begin{array}{l}\text { Genome } \\
\text { Biology }\end{array}$ & 10.806 & 19.041 & 2.794 & 9.479 \\
\hline $\begin{array}{l}\text { Journal of } \\
\text { Animal } \\
\text { Science and } \\
\text { Biotechnology }\end{array}$ & 4.167 & 4.392 & 1.690 & 1.333 \\
\hline $\begin{array}{l}\text { Stem Cell } \\
\text { Research and } \\
\text { Therapy }\end{array}$ & 5.116 & 5.554 & 1.267 & \\
\hline
\end{tabular}

Table 1: Impact Factors and Ranking of Journals (as of October 2020).

Of the 1081 articles examined, 786 (72.7\%) articles contain identifiable statistical methods (Table 2). From which, 2431 instances of statistical methods were identified. 51.79\% ( $n=405$; Figure 1) of the articles contain one or two statistical methods; with 14 as the maximum number of statistical methods identified from a single article [Tran., et al. [10]]. The methods identified were categorized into 15 application categories (Table 3). The top 3 categories; (a) parametric comparison of means, (b) correlation/ regression, and (c) post-hoc test; accounts for $54.59 \%$ of the instances. These are followed by (a) non-parametric comparison of 
means, (b) multiple comparison correction, (c) dimension reduction/multidimensional scaling, and (d) goodness of fit test; which accounts for another $26.94 \%$ of the instances. Collectively, these 7 application categories accounts for $81.53 \%$ of the instances.

\begin{tabular}{|c|c|c|c|}
\hline Journal Name & Date Range & $\begin{array}{c}\text { Number } \\
\text { of Articles } \\
\text { Surveyed }\end{array}$ & $\begin{array}{c}\text { Number of } \\
\text { Articles with } \\
\text { Statistical } \\
\text { Methods }\end{array}$ \\
\hline $\begin{array}{l}\text { Biological } \\
\text { Research }\end{array}$ & $\begin{array}{c}\text { January } 01,2020 \\
\text { to November } 30, \\
2020\end{array}$ & 55 & $48(87.3 \%)$ \\
\hline $\begin{array}{l}\text { BMC } \\
\text { Bioinformatics }\end{array}$ & $\begin{array}{l}\text { January } 01,2020 \text { to } \\
\text { February } 28,2020\end{array}$ & 72 & 31 (43.1\%) \\
\hline BMC Biology & \begin{tabular}{|c} 
January 01,2020 to \\
June 30,2020 \\
\end{tabular} & 111 & $79(71.2 \%)$ \\
\hline BMC Ecology & $\begin{array}{l}\text { January 01, } 2020 \text { to } \\
\text { December 31, } 2020\end{array}$ & 69 & 55 (79.7\%) \\
\hline $\begin{array}{l}\text { BMC } \\
\text { Evolutionary } \\
\text { Biology }\end{array}$ & $\begin{array}{c}\text { January } 01,2020 \text { to } \\
\text { July } 31,2020\end{array}$ & 96 & $51(53.13 \%)$ \\
\hline $\begin{array}{l}\text { BMC } \\
\text { Genomics }\end{array}$ & \begin{tabular}{|c} 
January 01,2020 to \\
January 31,2020 \\
\end{tabular} & 109 & $68(62.39 \%)$ \\
\hline $\begin{array}{l}\text { BMC } \\
\text { Microbiology }\end{array}$ & $\begin{array}{c}\text { January } 01,2020 \text { to } \\
\text { April 30, } 2020\end{array}$ & 99 & $81(81.0 \%)$ \\
\hline $\begin{array}{l}\text { BMC } \\
\text { Molecular and } \\
\text { Cell Biology } \\
\end{array}$ & $\begin{array}{c}\text { January } 01,2020 \\
\text { to November } 30, \\
2020\end{array}$ & 85 & $71(83.5 \%)$ \\
\hline $\begin{array}{l}\text { Cell and } \\
\text { Bioscience }\end{array}$ & $\begin{array}{c}\text { January } 01,2020 \\
\text { to September } 30, \\
2020\end{array}$ & 106 & $54(50.9 \%)$ \\
\hline $\begin{array}{l}\text { Genome } \\
\text { Biology }\end{array}$ & \begin{tabular}{|c} 
January 01,2020 to \\
April 30, 2020 \\
\end{tabular} & 100 & $83(83.0 \%)$ \\
\hline $\begin{array}{l}\text { Journal of } \\
\text { Animal } \\
\text { Science and } \\
\text { Biotechnology }\end{array}$ & $\begin{array}{c}\text { January } 01,2020 \\
\text { to September } 30, \\
2020\end{array}$ & 97 & 91 (93.8\%) \\
\hline $\begin{array}{l}\text { Stem Cell } \\
\text { Research and } \\
\text { Therapy } \\
\end{array}$ & $\begin{array}{l}\text { January } 01,2020 \text { to } \\
\text { February } 28,2020\end{array}$ & 82 & $74(90.2 \%)$ \\
\hline Total & & 1081 & $786(72.7 \%)$ \\
\hline
\end{tabular}

Table 2: Number of Articles Surveyed.

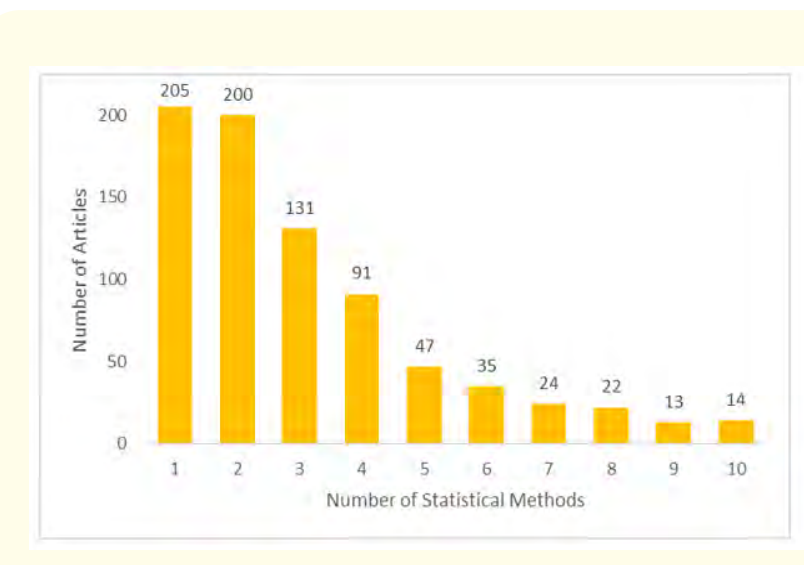

Figure 1: Distribution of Number of Statistical Methods.

In terms of individual statistical methods, the top 8 most frequent methods account for $52.04 \%$ of all the instances (Table 4 ). The methods are (a) t-test (13.00\%), (b) ANOVA (12.26\%), (c) unspecified and Pearson's correlation (9.79\%), (d) Benjamini and Hochberg's False Discovery Rate (FDR) (4.77\%), (e) Tukey's HSD (4.36\%), (f) Kruskal-Wallis Test (2.96\%), (g) Mann-Whitney U Test (2.80\%), and (h) Chi Square Test (2.10\%). These results are consistent with that of Loaiza Velásquez., et al. [2] as 7 of the 8 methods are common, except FDR. These results are also generally consistent with the common statistical methods identified by Al-Benna., et al. [8] and Meyr [7].

Mann-Whitney $U$ Test is often used as the non-parametric equivalent of independent samples t-test in most cases [11] despite differences in several assumptions [12]. Kruskal-Wallis Test is essentially the non-parametric version of one-way ANOVA [13]. While this underpins the importance of parametric and nonparametric comparison of means to biological sciences as these 4 methods account for $31.02 \%$ of the instances, it also illustrates the importance of non-parametric methods in biological sciences as biological data is often not normally distributed [14-16]. Besides being not normally distributed, multiple testing is also common in biology $[17,18]$; hence, it is not surprising that FDR is a commonly seen in publications.

Chi Square test is a common statistical method in biology with applications from clinical sciences [19] to population genetics [20] to omics analyses $[21,22]$. It is also often the first statistical test 
Science/Education Portraits VII: Statistical Methods Used in 1081 Papers Published in Year 2020 Across 12 Life Science Journals Under BioMed Central

taught in first year genetics; hence, has an important position in biology. Similar to Chi Square test, correlation is a staple in many fields of biology [23,24]. Of the 12 major post-hoc tests, Tukey's HSD is the only one that appears in the top 8 most frequent methods. One of the reasons may be its simplicity and closeness to ttest assuming equal variance in terms of calculation [25]. This also demonstrates the importance of t-test in the education of a biologist as 3 of the 8 most frequent methods (Tukey's HSD, ANOVA, and Mann-Whitney U Test) requires pre-requisite knowledge of t-test. The presence of Tukey's HSD also suggests the need for biologists to know what to do after null hypothesis of equal means in more than 2 samples, such as in ANOVA, is rejected. Taken together, these 8 statistical methods should form the basis of all statistical curriculum for biologists.

\begin{tabular}{|l|c|c|c|}
\hline \multicolumn{1}{|c|}{$\begin{array}{c}\text { Application } \\
\text { Category }\end{array}$} & Frequency & $\begin{array}{c}\text { Prevalence } \\
\text { (\%) }\end{array}$ & $\begin{array}{c}\text { Cumulative } \\
\text { Prevalence } \\
\text { (\%) }\end{array}$ \\
\hline $\begin{array}{l}\text { Parametric } \\
\text { Comparison of Means }\end{array}$ & 617 & $25.38 \%$ & $25.38 \%$ \\
\hline $\begin{array}{l}\text { Correlation/ } \\
\text { Regression }\end{array}$ & 459 & $18.88 \%$ & $44.26 \%$ \\
\hline Post-Hoc Test & 251 & $10.32 \%$ & $54.59 \%$ \\
\hline $\begin{array}{l}\text { Non-parametric } \\
\text { Comparison of Means }\end{array}$ & 231 & $9.50 \%$ & $64.09 \%$ \\
\hline $\begin{array}{l}\text { Multiple Comparison } \\
\text { Correction }\end{array}$ & 167 & $6.87 \%$ & $70.96 \%$ \\
\hline $\begin{array}{l}\text { Dimension } \\
\text { Reduction/ } \\
\text { Multidimensional } \\
\text { Scaling }\end{array}$ & 133 & $5.47 \%$ & $76.43 \%$ \\
\hline Goodness of Fit Test & 124 & $5.10 \%$ & $81.53 \%$ \\
\hline Graphing & 101 & $4.15 \%$ & $85.68 \%$ \\
\hline Normality Test & 59 & $2.43 \%$ & $88.11 \%$ \\
\hline Omics Analysis & 49 & $2.02 \%$ & $90.13 \%$ \\
\hline $\begin{array}{l}\text { Randomization/ } \\
\text { Permutation Test }\end{array}$ & 36 & $1.48 \%$ & $91.61 \%$ \\
\hline Survival Analysis & 34 & $1.40 \%$ & $93.01 \%$ \\
\hline $\begin{array}{l}\text { Equality of Variance } \\
\text { test }\end{array}$ & 32 & $1.32 \%$ & $94.32 \%$ \\
\hline $\begin{array}{l}\text { Measure of } \\
\text { Dispersion }\end{array}$ & 125 & $5.14 \%$ & $100.00 \%$ \\
\hline Others & & & $94.86 \%$ \\
\hline
\end{tabular}

Table 3: Relative Prevalence of Statistical Methods. Prevalence is defined as the quotient between the number of frequencies in each category and the total number of frequencies $(n=2431)$. Cumulative prevalence is the summation of prevalence up to the category, with the total cumulative prevalence of $100 \%$

\begin{tabular}{|c|c|c|}
\hline $\begin{array}{l}\text { Application Category/ } \\
\text { Statistical Method }\end{array}$ & $\begin{array}{l}\text { Frequency } \\
\text { (N) }\end{array}$ & $\begin{array}{c}\text { Prevalence } \\
(\%)\end{array}$ \\
\hline \multicolumn{3}{|l|}{ Correlation/Regression (18.88\%) } \\
\hline Unspecified Correlation & 147 & $6.05 \%$ \\
\hline Pearson's correlation & 91 & $3.74 \%$ \\
\hline Spearman's correlation & 46 & $1.89 \%$ \\
\hline General Linear Model (GLM) & 33 & $1.36 \%$ \\
\hline Linear Regression & 28 & $1.15 \%$ \\
\hline Unspecified Regression & 15 & $0.62 \%$ \\
\hline Linear Mixed Effect Model & 10 & $0.41 \%$ \\
\hline Polynomial Contrasts & 9 & $0.37 \%$ \\
\hline ADONIS & 7 & $0.29 \%$ \\
\hline Cox's Regression & 6 & $0.25 \%$ \\
\hline Generalized Linear Mixed Model & 6 & $0.25 \%$ \\
\hline Logistic Regression & 6 & $0.25 \%$ \\
\hline Non-Linear Regression & 6 & $0.25 \%$ \\
\hline Mantel-Haenszel Method & 5 & $0.21 \%$ \\
\hline Multiple Regression & 5 & $0.21 \%$ \\
\hline Inter-Rater Agreement & 4 & $0.16 \%$ \\
\hline Kendall's Correlation & 4 & $0.16 \%$ \\
\hline Redundancy Analysis (RDA) & 3 & $0.12 \%$ \\
\hline Fractional Regression & 3 & $0.12 \%$ \\
\hline Generalized Additive Model & 3 & $0.12 \%$ \\
\hline Lasso Regression & 3 & $0.12 \%$ \\
\hline Others $(\mathrm{N}<3)$ & 19 & $0.78 \%$ \\
\hline \multicolumn{3}{|c|}{ Dimension Reduction/Multidimensional Scaling (5.47\%) } \\
\hline $\begin{array}{l}\text { Principal Component Analysis } \\
\text { (PCA) }\end{array}$ & 40 & $1.65 \%$ \\
\hline $\begin{array}{l}\text { Principal Co-Ordinates Analysis } \\
\text { (PCoA) }\end{array}$ & 17 & $0.70 \%$ \\
\hline $\begin{array}{l}\text { Linear Discriminant } \\
\text { Analysis (LDA) }\end{array}$ & 15 & $0.62 \%$ \\
\hline $\begin{array}{l}\text { Linear Discriminant } \\
\text { Analysis Effect Size (LEfSe) }\end{array}$ & 14 & $0.58 \%$ \\
\hline Shannon Index & 10 & $0.41 \%$ \\
\hline Simpson Index & 6 & $0.25 \%$ \\
\hline Neighbor-Joining Method & 5 & $0.21 \%$ \\
\hline $\begin{array}{l}\text { Non-Metric } \\
\text { Multidimensional Scaling } \\
\text { (NMDS) }\end{array}$ & 4 & $0.16 \%$ \\
\hline $\begin{array}{l}\text { Root Mean Squared Distance } \\
\text { (RMSD) }\end{array}$ & 4 & $0.16 \%$ \\
\hline $\begin{array}{l}\text { Uniform Manifold Approximation } \\
\text { and Projection }\end{array}$ & 4 & $0.16 \%$ \\
\hline UPGMA Cluster Analysis & 4 & $0.16 \%$ \\
\hline
\end{tabular}


Science/Education Portraits VII: Statistical Methods Used in 1081 Papers Published in Year 2020 Across 12 Life Science Journals Under BioMed Central

\begin{tabular}{|c|c|c|}
\hline $\begin{array}{l}\text { t-Distributed Stochastic Neighbor } \\
\text { Embedding }\end{array}$ & 3 & $0.12 \%$ \\
\hline Others $(\mathrm{N}<3)$ & 7 & $0.29 \%$ \\
\hline \multicolumn{3}{|l|}{ Equality of Variance Test (1.32\%) } \\
\hline Levene's Test & 13 & $0.53 \%$ \\
\hline F-Test & 9 & $0.37 \%$ \\
\hline Bartlett's Test & 5 & $0.21 \%$ \\
\hline Others $(\mathrm{N}<3)$ & 5 & $0.21 \%$ \\
\hline \multicolumn{3}{|l|}{ Goodness of Fit Test (5.10\%) } \\
\hline Chi Square Test & 51 & $2.10 \%$ \\
\hline Fisher's Exact Test & 48 & $1.97 \%$ \\
\hline Likelihood Ratio Test & 6 & $0.25 \%$ \\
\hline Mantel Test & 5 & $0.21 \%$ \\
\hline Wald Test & 5 & $0.21 \%$ \\
\hline Hardy-Weinberg Equilibrium Test & 4 & $0.16 \%$ \\
\hline I2 Test & 3 & $0.12 \%$ \\
\hline Kullback-Leibler Distance & 2 & $0.08 \%$ \\
\hline \multicolumn{3}{|l|}{ Graphing (4.15\%) } \\
\hline Box Plot & 29 & $1.19 \%$ \\
\hline Heatmap & 22 & $0.90 \%$ \\
\hline Error Bar & 12 & $0.49 \%$ \\
\hline Bar Plot & 9 & $0.37 \%$ \\
\hline Scatter Plot & 7 & $0.29 \%$ \\
\hline Dot Plot & 4 & $0.16 \%$ \\
\hline $\begin{array}{l}\text { Receiver Operating Characteristic } \\
\text { Curve (ROC curve) }\end{array}$ & 4 & $0.16 \%$ \\
\hline Volcano Plot & 4 & $0.16 \%$ \\
\hline Others $(\mathrm{N}<3)$ & 10 & $0.41 \%$ \\
\hline \multicolumn{3}{|l|}{ Measure of Dispersion $(0.53 \%)$} \\
\hline Coefficient of Variation & 6 & $0.25 \%$ \\
\hline Standard Error & 4 & $0.16 \%$ \\
\hline Others $(\mathrm{N}<3)$ & 3 & $0.12 \%$ \\
\hline \multicolumn{3}{|c|}{ Multiple Comparison Correction (6.87\%) } \\
\hline $\begin{array}{l}\text { Benjamini and Hochberg's False } \\
\text { Discovery Rate (FDR) }\end{array}$ & 116 & $4.77 \%$ \\
\hline Bonferroni Correction & 48 & $1.97 \%$ \\
\hline Others $(\mathrm{N}<3)$ & 3 & $0.12 \%$ \\
\hline \multicolumn{3}{|c|}{ Non-Parametric Comparison of Means (9.50\%) } \\
\hline Kruskal-Wallis Test & 72 & $2.96 \%$ \\
\hline Mann-Whitney U Test & 68 & $2.80 \%$ \\
\hline Wilcoxon Rank-Sum Test & 40 & $1.65 \%$ \\
\hline Analysis of Similarities (ANOSIM) & 22 & $0.90 \%$ \\
\hline Unspecified Wilcoxon Test & 12 & $0.49 \%$ \\
\hline Wilcoxon Signed-Rank Test & 11 & $0.45 \%$ \\
\hline Friedman Test & 3 & $0.12 \%$ \\
\hline
\end{tabular}

\begin{tabular}{|c|c|c|}
\hline Others $(\mathrm{N}<3)$ & 3 & $0.12 \%$ \\
\hline \multicolumn{3}{|l|}{ Normality Test (2.43\%) } \\
\hline Shapiro-Wilk Test & 27 & $1.11 \%$ \\
\hline Kolmogorov-Smirnov Test & 25 & $1.03 \%$ \\
\hline Anderson-Darling Test & 3 & $0.12 \%$ \\
\hline Others $(\mathrm{N}<3)$ & 4 & $0.16 \%$ \\
\hline \multicolumn{3}{|l|}{ Omics Analysis (2.02\%) } \\
\hline $\begin{array}{l}\text { Gene Ontology Enrichment } \\
\text { Analysis }\end{array}$ & 24 & $0.99 \%$ \\
\hline $\begin{array}{l}\text { Analysis of Molecular Variance } \\
\text { (AMOVA) }\end{array}$ & 6 & $0.25 \%$ \\
\hline DESeq2 & 3 & $0.12 \%$ \\
\hline Feed Conversion Ratio & 3 & $0.12 \%$ \\
\hline Others $(\mathrm{N}<3)$ & 13 & $0.53 \%$ \\
\hline \multicolumn{3}{|c|}{ Parametric Comparison of Means (25.38\%) } \\
\hline t-Test & 316 & $13.00 \%$ \\
\hline Analysis of Variance (ANOVA) & 298 & $12.26 \%$ \\
\hline Z-Test & 3 & $0.12 \%$ \\
\hline \multicolumn{3}{|l|}{ Post-Hoc Test (10.32\%) } \\
\hline Tukey's HSD & 106 & $4.36 \%$ \\
\hline Unspecified Post-Hoc Test & 44 & $1.81 \%$ \\
\hline Duncan's multiple range Test & 23 & $0.95 \%$ \\
\hline Dunnett's Test & 20 & $0.82 \%$ \\
\hline Dunn's Test & 17 & $0.70 \%$ \\
\hline $\begin{array}{l}\text { Fisher's Least Significant Differ- } \\
\text { ence (LSD) }\end{array}$ & 13 & $0.53 \%$ \\
\hline Holm-Sidak Test & 6 & $0.25 \%$ \\
\hline $\begin{array}{l}\text { Student-Newman-Keuls (SNK) } \\
\text { Test }\end{array}$ & 5 & $0.21 \%$ \\
\hline Scheffe's Test & 4 & $0.16 \%$ \\
\hline Bonferroni Test & 3 & $0.12 \%$ \\
\hline Conover-Iman Test & 3 & $0.12 \%$ \\
\hline Post-Hoc t-Test & 3 & $0.12 \%$ \\
\hline Others $(\mathrm{N}<3)$ & 4 & $0.16 \%$ \\
\hline \multicolumn{3}{|c|}{ Randomization/Permutation Test (1.48\%) } \\
\hline $\begin{array}{l}\text { Permutational Multivariate Anal- } \\
\text { ysis of Variance (PERMANOVA) }\end{array}$ & 21 & $0.86 \%$ \\
\hline Permutation Test & 7 & $0.29 \%$ \\
\hline Others $(\mathrm{N}<3)$ & 8 & $0.33 \%$ \\
\hline \multicolumn{3}{|l|}{ Survival Analysis (1.40\%) } \\
\hline Log-Rank Test & 24 & $0.99 \%$ \\
\hline Kaplan-Meier Analysis & 10 & $0.41 \%$ \\
\hline Others $(\mathrm{N}<3)$ & 125 & $5.14 \%$ \\
\hline
\end{tabular}

Table 4: Breakdown of Statistical Methods. 
Prevalence is defined as the quotient between the number of frequencies in each category and the total number of frequencies $(n=2431)$. Cumulative prevalence is the summation of prevalence up to the category, with the total cumulative prevalence of $100 \%$.

\section{Conclusion}

The top 8 most frequent methods identified from 1081 articles are (a) t-test, (b) ANOVA, (c) unspecified and Pearson's correlation, (d) Benjamini and Hochberg's False Discovery Rate (FDR), (e) Tukey's HSD, (f) Kruskal-Wallis Test, (g) Mann-Whitney U Test, and (h) Chi Square Test.

\section{Supplementary Materials}

Data file for this study can be downloaded at http://bit.ly/ SEP7_Statistics.

\section{Conflict of Interest}

The authors declare no conflict of interest.

\section{Disclaimer}

The views expressed by the authors are that of the authors rather than the views of their affiliated institutions.

\section{Bibliography}

1. Pearl R. "The Service and Importance of Statistics to Biology". American Statistical Association 14.105 (1914): 40-48.

2. Loaiza Velásquez N., et al. "Which Statistics Should Tropical Biologists Learn?" Revista de Biología Tropical 59.3 (2011): 983992.

3. Colon-Berlingeri $\mathrm{M}$ and Burrowes PA. "Teaching Biology Through Statistics: Application of Statistical Methods in Genetics and Zoology Courses". CBE-Life Sciences Education 10.3 (2011): 259-267.

4. Metz AM. "Teaching Statistics in Biology: Using Inquiry-Based Learning to Strengthen Understanding of Statistical Analysis in Biology Laboratory Courses". CBE-Life Sciences Education 7.3 (2008): 317-326.

5. Lee CM., et al. "Statistics in the Pharmacy Literature". Annals of Pharmacotherapy 38.9 (2004): 1412-1418.

6. Skinner J. "Statistics for Immunologists". Current Protocols in Immunology 122.1 (2018): 54.
7. Meyr AJ. "A 5-Year Review of Statistical Methods Presented in The Journal of Foot and Ankle Surgery". The Journal of Foot and Ankle Surgery 49.5 (2010): 471-474.

8. Al-Benna S., et al. "Descriptive and Inferential Statistical Methods Used in Burns Research". Burns 36.3 (2010): 343-346.

9. Hammer AS and Buffington CA. "Survey of Statistical Methods Used in the Veterinary Medical Literature". Journal of the American Veterinary Medical Association 205.2 (1994): 344-345.

10. Tran HTN., et al. "A Benchmark of Batch-Effect Correction Methods for Single-Cell RNA Sequencing Data". Genome Biology 21.1 (2020): 12 .

11. Dowdy S., et al. "Statistics for Research". John Wiley and Sons (2011).

12. Fay MP and Proschan MA. "Wilcoxon-Mann-Whitney or t-test? On Assumptions for Hypothesis Tests and Multiple Interpretations of Decision Rules". Statistics Surveys 4 (2010): 1-39.

13. Kruskal WH and Wallis WA. "Use of Ranks in One-Criterion Variance Analysis". Journal of the American Statistical Association 47.260 (1952): 583-621.

14. Mar JC. "The Rise of the Distributions: Why Non-Normality is Important for Understanding the Transcriptome and Beyond". Biophysical Reviews 11.1 (2019): 89-94.

15. Bono R., et al. "Non-normal Distributions Commonly Used in Health, Education, and Social Sciences: A Systematic Review". Frontiers in Psychology 8 (2017): 1602.

16. Wittkowski KM and Song T. "Nonparametric Methods for Molecular Biology". Methods In Molecular Medicine 620 (2010): 105-153.

17. Korthauer K., et al. "A Practical Guide to Methods Controlling False Discoveries in Computational Biology". Genome Biology 20.1 (2019): 118.

18. Saxon E. "Multiple Comparisons". BMC Biology 13.1 (2015): 86.

19. Al-Najjar D., et al. "CoVID-19 Symptoms Analysis of Deceased and Recovered Cases using Chi-square test". European Review for Medical and Pharmacological Sciences 24.21 (2020): 11428-11431. 
20. Kamarudin NJ., et al. "A Simulation Study on the Effects of Founding Population Size and Number of Alleles Per Locus on the Observed Population". EC Veterinary Science 5.8 (2020): 176-180.

21. Li W-M., et al. "Prognostic Utility of FBLN2 Expression in Patients With Urothelial Carcinoma”. Frontiers in Oncology 10 (2020): 570340.

22. Wang C., et al. "High Expression of RING Finger Protein 126 Predicts Unfavorable Prognosis of Epithelial Ovarian Cancer". Medical Science Monitor 26 (2020): e921370.

23. Mukaka MM. "Statistics Corner: A Guide to Appropriate Use of Correlation Coefficient in Medical Research". Malawi Medical Journal 24.3 (2012): 69-71.

24. Armstrong RA., et al. "The Use of Correlation and Regression Methods in Optometry". Clinical and Experimental Optometry 88.2 (2005): 81-88.

25. Haynes W. "Tukey's Test”. In: Dubitzky W, Wolkenhauer O, Cho K-H, Yokota H, editors. Encyclopedia of Systems Biology. New York, NY: Springer New York (2013): 2303-2304.

\section{Assets from publication with us}

- Prompt Acknowledgement after receiving the article

- Thorough Double blinded peer review

- Rapid Publication

- Issue of Publication Certificate

- High visibility of your Published work

Website: www.actascientific.com/

Submit Article: www.actascientific.com/submission.php

Email us: editor@actascientific.com

Contact us: +919182824667

Citation: Maurice HT Ling., et al. "Science/Education Portraits VII: Statistical Methods Used in 1081 Papers Published in Year 2020 Across 12 Life Science Journals Under BioMed Central". Acta Scientific Nutritional Health 5.3 (2021): 06-12. 